\title{
Assessment of Impact of Foreign Direct Investment in India FDI in Banking and Finance
}

Sekar $\mathrm{K}^{*}$

Lecturer in Department of Commerce, M.S. Ramaiah College of Arts Science and Commerce, India

\begin{abstract}
The Foreign Direct Investment (FDI) environment in India has undergone a drastic change since the economic reforms in 1991. The positive changes can be particularly attributed to the evolving policy framework. The main thrust of the financial sector reforms has been the creation of efficient and stable financial institutions and development of the markets, especially the money and government securities market. Indian banks going global and many global banks setting up shops in India, the Indian banking system is set to involve into a totally new level it will help the banking system grow in strength going into the future. India offers attractive investment opportunities for foreign companies and has adopted a number of policies to attract foreign direct investment into the country and the country seems to offer perhaps one of the most liberal FDI regimes in Asia. It's even reviewed that the investment climate has not improved in India as a result of lack of good governance, corruption, political instability and disturbance, bureaucratic inertia, and poor law and order situation. Indian government incentives to foreign investors, particularly Special Economic Zones, the Indian regulatory environment as it affects investment, and the effect of India's global, regional, and bilateral trade agreements on investment from the United States and other countries.
\end{abstract}

Keywords: Foreign Direct Investment; Finance; Banking; Globalization; Development

\section{Introduction}

Today India is one of the most stirring and promising markets in the globe. Technical and Skilled human resources are the finest available in the world. Private sector is the lifeblood of economic activity in India which is energetic and well spirited. Middle class population of India is greater than the population of the USA or the European Union which provide India a key place in International competition. Under the new economic policy, India provides open and liberal economic atmosphere and offers considerable scope for foreign direct investment, joint ventures and collaborations. Due to economic crises in 1991, Economic environment at global level was changed. India was recognized the need of advanced technology in science and business therefore India made a new economic policy in July 1991. According to new economic policy foreign investments were greatly essential for India to become regularly competent in International trade [1]. This new policy removed all unnecessary rules and given liberal environment to foreign investors for FDI inflows under automatic route. FDI have helped India to attain a financial stability and economic growth with the help of investments in different sectors. FDI has boosted the economic life of India and on the other hand there are critics who have blamed the government for ousting the domestic inflows. After liberalization of Trade policies in India, there has been a positive GDP growth rate in Indian economy. Foreign direct investments helps in developing the economy by generating employment to the unemployed, Generating revenues in the form of tax and incomes, Financial stability to the government, development of infrastructure, backward and forward linkages to the domestic firms for the requirements of raw materials, tools, business infrastructure, and act as support for financial system. Forward and back ward linkages are developed to support the foreign firm with supply of raw and other requirements. It helps in generation of employment and also helps poverty eradication. There are many businesses or individuals who would earn their lively hood through the foreign investments. There are legal and financial consultants who also guide in the early stage of establishment of firm. Foreign investments mean both foreign portfolio investments and foreign direct investments (FDI). FDI brings better technology and management, marketing networks and offers competition, the latter helping Indian companies improve, quite apart from being good for consumers. Alongside opening up of the FDI regime, steps were taken to allow foreign portfolio investments into the Indian stock market through the mechanism of foreign institutional investors. The objective was not only to facilitate nondebt creating foreign capital inflows but also to develop the stock market in India, lower the cost of capital for Indian enterprises and indirectly improve corporate governance structures. On their part, large Indian companies have been allowed to raise capital directly from international capital markets through commercial borrowings and depository receipts having underlying Indian equity. Thus the country adopted a two-pronged strategy: one to attract FDI which is associated with multiple attendant benefits of technology, access to export markets, skills, management techniques, etc. and two to encourage portfolio capital flows which ease the financing constraints of Indian enterprises. Foreign technology induction can be encouraged through FDI and through foreign technology collaboration agreements. The sectors which have resources but do not have the required technology acquire foreign technology collaboration through RBI or Government approvals. The total number of approvals recorded for the period of 2000 to 2010 by the RBI, SIA and FIPB is 8080 . The RBI has approved 4580 proposal whereas SIA and FIPB have approved 3500. Technical collaborations have put a positive effect on the domestic firms. It helped in establishing technology transfers. An Indian company may receive Foreign Direct Investment under the two routes as given under:

*Corresponding author: Sekar K, Lecturer in Department of Commerce, M.S. Ramaiah College of Arts Science and Commerce, India, Tel: (91-80)-23600966; E-mail: shekarmsrcasc@gmail.com

Receved September 01, 2014; Accepted January 26, 2015; Published February 12,2015

Citation: Sekar K (2015) Assessment of Impact of Foreign Direct Investment in India FDI in Banking and Finance. J Entrepren Organiz Manag 4: 127. doi: 10.4172/2169-026X.1000127

Copyright: (c) 2015 Sekar K. This is an open-access article distributed under the terms of the Creative Commons Attribution License, which permits unrestricted use, distribution, and reproduction in any medium, provided the original author and source are credited. 


\section{Automatic route}

FDI in sectors/activities to the extent permitted under the automatic route does not require any prior approval either of the Government or the Reserve Bank of India.

\section{Government route}

FDI in activities not covered under the automatic route requires prior approval of the Government which is considered by the Foreign Investment Promotion Board (FIPB) [2]. Department of Economic Affairs, and Ministry of Finance.

\section{FDI involved in following sectors in India}

Service Sector, Computer Software and Hardware, Telecommunication, Construction Activities, Automobile Industry, Power, Chemical, Real Estate, Drugs and Pharmaceuticals, Electrical Equipments, Cement and Gypsum Product, Metallurgical Industries, Electronics, Consultancy Services, Petroleum and Natural Gas, Hotel and Tourism, Trading, Textiles, Information and Broadcasting, Sea Transport, Fermentation Industries, Hospital and Diagnostic Centers, Air Transport, Rubber Goods, Machine Tools, Sport, Industrial Machinery, Agricultural Machinery, Paper and Pulp, Agricultural Services, Diamond, Gold Ornaments, Glass, Industrial Instruments, Photographic Raw Film and Paper, Scientific Instruments, Nonconventional Energy, Leather and Leather Goods, Tea and Coffee, Sugar, Vegetable Oils and Vanaspati, Railway Related Components, Education, Fertilizers, Earth-moving Machinery, Printing of Books, Soaps, Cosmetics and Toilet, Medical and Surgical Appliances, Mining, Ceramics, Boilers and Steam Generating Plants, Dye-stuffs, Coal Production, Coir, Timber Product, Defense Industries [3].

\section{Restricted sectors for FDI in India}

Atomic energy, Nidhi company, Betting and gambling, Chit fund business, Plantation or agricultural activities, Real estate business, Business in Transferable Development Rights, Lottery business, Retail trading, Railway transport, Mining of chrome, zinc, gold, diamonds, copper, iron, gypsum, manganese, and sulfur, Ammunition and arms [4].

\section{Review of Literature}

\section{Heiwai}

The paper builds on the idea that economic reforms in China were designed to attract foreign direct investment (FDI), while the opposite happened in India. We empirically examine how these different reform approaches affect foreign-invested enterprises' (FIE) and domestic firms' perceptions about the host country's business environment. Using World Bank survey data, we find that FIEs in India perceive more obstacles to business operations and development relative to domestic firms, especially on issues related to government regulations and legal institutions [5].

\section{Mohammad}

The paper examines co-integration and the causal relationship between Foreign Direct Investment (FDI) and the economic output or Gross Domestic Product (GDP) in the both short and long run of Bangladesh, Pakistan and India over the period of 1972-2008 [6]. Three econometric models, viz. Augmented Dickey-Fuller (ADF) test, Engle-Granger two-step co-integration test, Vector error correction mechanism (VECM) have been used. This study also used Granger Causality (GC) to find the directional relationship between FDI and
GDP. The results suggest that there is no co-integration between FDI and GDP in the both long and short run in Bangladesh and India.

\section{Dr. Patil Usha N}

The Government of India was initially very apprehensive of the introduction of the Foreign Direct Investment in the Retail Sector in India. The unorganized retail sector as has been mentioned earlier occupies $98 \%$ of the retail sector and the rest $2 \%$ is contributed by the organized sector [7]. Hence one reason why the government feared the surge of the Foreign Direct Investments in India was the displacement of labour. The unorganized retail sector contributes about $14 \%$ to the GDP and absorbs about 7\% of our labour force. Hence the issue of displacement of labour consequent to FDI is of primal importance. There are different viewpoints on the impact of FDI in the retail sector in India.

\section{Piyaareekul}

The paper examines the interaction on intra-industry trade (IIT) and foreign direct investment (FDI) with special attention to the Association of Southeast Asian Nations (ASEAN). We introduce the $2 \times 3 \times 3$ knowledge-capital model, recently proposed by Baltagi et al. and Uttama and Péridy. The theoretical implications are suggested, not only how IIT is determined by country characteristics, such as similarity in market size and factor differentials, but also trade costs as well as regional economic integration.

\section{Objective of Study}

* To understand the impact of FDI in India on banking and finance.

* To exhibit the analysis of FDI's in India on banking and finance.

\section{Research Methodology}

This research is a descriptive study in nature. The secondary data was collected from various journals, magazines, and websites particularly from the Department of Industrial Policy and Promotion, Ministry of Commerce and Industry etc [8]. The study is based on the time period from 2011-2012. Graphs and tables have also been used where ever required to depict statistical data of FDI during the study period.

\section{Analysis of FDI inflows and interpretation}

Table 1 shows the amount of FDI inflows from April 2011 to

\begin{tabular}{|c|c|c|}
\hline Financial Year 2011-2012 (April-March) & \multicolumn{2}{|c|}{ Amount of FDI inflows } \\
\hline & ( in Rs Crore) & in US\$ mn) \\
\hline 11-Apr & 13,847 & 3,121 \\
\hline 11-May & 20,946 & 4,664 \\
\hline 11-Jun & 25,371 & 5,656 \\
\hline 11-Jul & 4,886 & 1,099 \\
\hline 11-Aug & 12,814 & 2,830 \\
\hline 11-Sep & 8,407 & 1,766 \\
\hline 11-Oct & 5,715 & 1,161 \\
\hline 11-Nov & 12,909 & 2,538 \\
\hline 11-Dec & 7,124 & 1,353 \\
\hline 11-Jan & 10,288 & 2,004 \\
\hline 11-Feb & 10,874 & 2,211 \\
\hline 2011-12 (up to February 2012)\# & 133,181 & 28,403 \\
\hline 2010 (up to February 2011) & 83,687 & 18,354 \\
\hline age growth over last year & $(+) 59 \%$ & $(+) 55 \%$ \\
\hline
\end{tabular}

Table 1: FDI equity inflows (month-wise) during the financial year 2011-12. 
Citation: Sekar K (2015) Assessment of Impact of Foreign Direct Investment in India FDI in Banking and Finance. J Entrepren Organiz Manag 4: 127. doi: 10.4172/2169-026X.1000127

Page 3 of 4

February, 2012. It shows the amount in Rs crore and in US \$ mn. The highest FDI inflows in the country is in the month June 2011 i.e. 25371 in Rs crores and 5656 in US \$ mn. Other months shows the fluctuating trend.

Chart 1 shows the total FDI inflows during the time period April 2011 to February, 2012. The FDI inflow shows a fluctuating trend in different months

\section{Sectors attracting highest FDI equity inflows in India}

Table 2 shows the favorite and leading sectors for FDI in India. According to FDI report Service sector is the favorite sector with highest FDI inflow 20\%. After service sector Telecommunication and Computer hardware and software is the next favorite sector with $8 \%$ and $7 \%$. There is a good future prospect for investors in other sectors also like Housing sector and power sector.

Chart 2 shows that service sector has the highest FDI inflow attracting 20\% share. Other sectors have less FDI inflow in India. Telecommunication, computer software attracts only 7\% FDI.

\section{(in US\$mn.)}

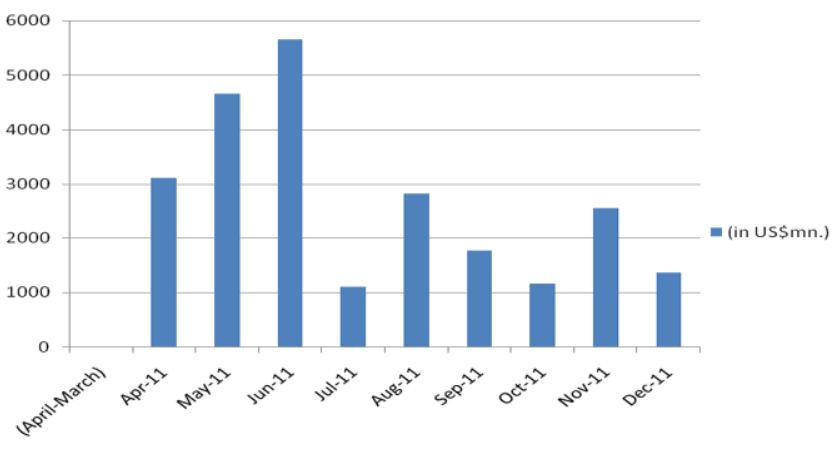

Chart 1: Shows amount of FDI inflows.

\begin{tabular}{|c|c|c|c|c|c|c|}
\hline Ranks & Sector & $\begin{array}{l}\text { 2009-10 } \\
\text { (April-March) }\end{array}$ & $\begin{array}{c}2010-11 \\
\text { (April- March) }\end{array}$ & $\begin{array}{l}\text { 2011-2012 } \\
\text { (April-Feb) }\end{array}$ & $\begin{array}{l}\text { Cumulative inflows } \\
\text { (April 00-Feb 12) }\end{array}$ & $\begin{array}{l}\% \text { age to total inflows } \\
\text { in terms of US\$ }\end{array}$ \\
\hline 1 & $\begin{array}{c}\text { Services Sector } \\
\text { ( financial and non-financial) }\end{array}$ & $\begin{array}{l}19,945 \\
\mathbf{( 4 , 1 7 6 )}\end{array}$ & $\begin{array}{l}15,053 \\
(\mathbf{3}, \mathbf{2 9 6})\end{array}$ & $\begin{array}{l}23,865 \\
\mathbf{( 5 , 0 5 9 )}\end{array}$ & $\begin{array}{l}144,973 \\
(32,193)\end{array}$ & $20 \%$ \\
\hline 2 & $\begin{array}{l}\text { Telecommunications } \\
\text { (radio paging, cellular mobile, basic telephone services) }\end{array}$ & $\begin{array}{l}12,270 \\
(\mathbf{2}, 539)\end{array}$ & $\begin{array}{c}7,542 \\
(1,665)\end{array}$ & $\begin{array}{c}9,002 \\
(1,995)\end{array}$ & $\begin{array}{c}57,069 \\
(\mathbf{1 2 , 5 5 0 )}\end{array}$ & $8 \%$ \\
\hline 3 & $\begin{array}{l}\text { Construction Activities } \\
\text { (including roads and highways) }\end{array}$ & $\begin{array}{l}13,469 \\
(\mathbf{2}, \mathbf{8 5 2})\end{array}$ & $\begin{array}{c}4,979 \\
(\mathbf{1}, \mathbf{1 0 3})\end{array}$ & $\begin{array}{l}12,286 \\
\mathbf{( 2 , 5 2 0 )}\end{array}$ & $\begin{array}{c}50,867 \\
(11,157)\end{array}$ & $7 \%$ \\
\hline 4 & Computer Software and Hardware & $\begin{array}{l}4,127 \\
(872)\end{array}$ & $\begin{array}{l}3,551 \\
\mathbf{( 7 8 0 )}\end{array}$ & $\begin{array}{l}3,524 \\
\mathbf{( 7 4 1 )}\end{array}$ & $\begin{array}{c}49,838 \\
(11,150)\end{array}$ & $7 \%$ \\
\hline 5 & Housing and Real Estate & $\begin{array}{l}14,027 \\
\mathbf{( 2 , 9 3 5 )}\end{array}$ & $\begin{array}{c}5,600 \\
(\mathbf{1}, \mathbf{2 2 7})\end{array}$ & $\begin{array}{l}3,326 \\
\mathbf{( 7 0 8 )}\end{array}$ & $\begin{array}{c}49,600 \\
(\mathbf{1 1}, \mathbf{0 9 0})\end{array}$ & $7 \%$ \\
\hline 6 & Drugs and Pharmaceuticals & $\begin{array}{l}1,006 \\
\mathbf{( 2 1 3 )}\end{array}$ & $\begin{array}{c}961 \\
\mathbf{( 2 0 9 )}\end{array}$ & $\begin{array}{l}14,498 \\
\mathbf{( 3 , 2 1 1 )}\end{array}$ & $\begin{array}{l}42,761 \\
(\mathbf{9}, 174)\end{array}$ & $6 \%$ \\
\hline 7 & Power & $\begin{array}{c}6,138 \\
(\mathbf{1}, \mathbf{2 7 2})\end{array}$ & $\begin{array}{c}5,796 \\
(\mathbf{1}, \mathbf{2 7 2})\end{array}$ & $\begin{array}{c}7,494 \\
(\mathbf{1}, \mathbf{6 1 6})\end{array}$ & $\begin{array}{l}33,030 \\
(7,262)\end{array}$ & $4 \%$ \\
\hline 8 & Automobile Industry & $\begin{array}{c}5893 \\
(\mathbf{1}, \mathbf{2 3 6})\end{array}$ & $\begin{array}{c}5864 \\
(\mathbf{1}, 299)\end{array}$ & $\begin{array}{l}3,691 \\
(\mathbf{7 9 3})\end{array}$ & $\begin{array}{l}30,129 \\
(\mathbf{6}, \mathbf{6 2 7})\end{array}$ & $4 \%$ \\
\hline 9 & Metalurgical Industries & $\begin{array}{l}1,999 \\
\mathbf{( 4 2 0 )}\end{array}$ & $\begin{array}{c}5,023 \\
(\mathbf{1}, \mathbf{0 9 8})\end{array}$ & $\begin{array}{c}8,242 \\
(1,765)\end{array}$ & $\begin{array}{l}26,830 \\
(\mathbf{6}, \mathbf{0 2 0})\end{array}$ & $4 \%$ \\
\hline 10 & Petroleum and Natural Gas & $\begin{array}{l}1,297 \\
\mathbf{( 2 6 6 )}\end{array}$ & $\begin{array}{l}2,543 \\
\mathbf{( 5 5 6 )}\end{array}$ & $\begin{array}{c}951 \\
\mathbf{( 2 0 2 )}\end{array}$ & $\begin{array}{l}14,612 \\
(3,339)\end{array}$ & $2 \%$ \\
\hline
\end{tabular}

Table 2: Sectors attracting highest FDI equity inflows in India.

\section{Statement one Country-wise FDI inflows from April 2000 to February 2012}

Table 3 Depicts the country having the highest FDI in India. The report shows that the Mauritius country has the highest foreign investor in India with $39.25 \%$. After Mauritius, Singapore and Japan invest the highest FDI in India with $10.46 \%$ and $7.53 \%$ respectively. U.S.A also gets $4^{\text {th }}$ position in FDI in India.

\section{Findings}

* FDI is an important stimulus for the economic growth of India [9].

* After above analysis, we can say that FDI has good future growth in Retailing and Real estate sector in India.

* Service sector is first and banking and insurance sector is second segment of which pick the growth in second decade of reforms.

* FDI create high perks jobs for skilled employee in Indian service sector.

* Mauritius and Singapore is the 2 top countries which has maximum FDI in India.

* FDI plays an important role in the development of infrastructure because many countries invest in the infrastructure sector and service and banking finance sectors.

* FDI shown a tremendous growth in second decade (2000 [10].

* Atomic Energy and Railway Transport are some important and life line of any country. Therefore India also restricted FDI in these sectors.

* The service sector has attracted highest (21 per cent) FDI inflows; then Computer software, and hardware ( 9 per cent), telecommunication sector (8 per cent) and Housing and Real estate (7 per cent) during 2008 to August 2010. Mauritius (42 per cent to total inflows of FDI) has been largest investor in India, followed by -2011) that is three times then the first decade of FDI in services sector 


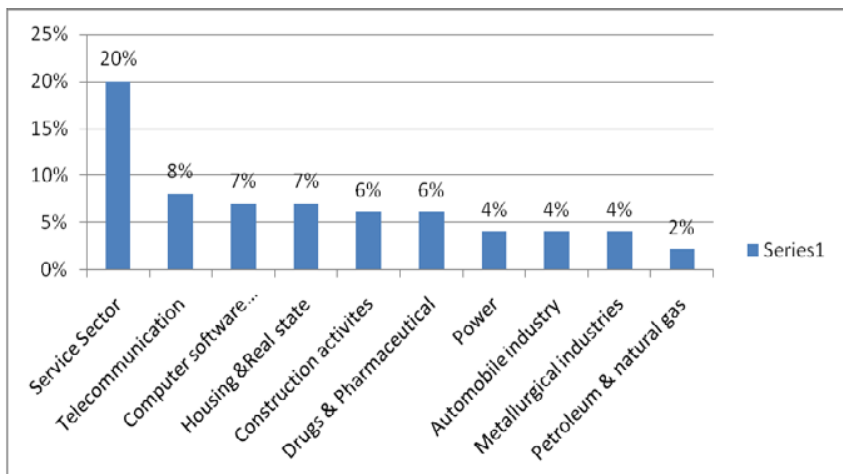

Chart 2: FDI Equity Inflows in India.

\begin{tabular}{|c|c|c|c|c|}
\hline \multirow{2}{*}{ S.NO } & \multirow{2}{*}{ Country } & \multicolumn{2}{|c|}{$\begin{array}{c}\text { Amount of foreign } \\
\text { Direct investment Inflows }\end{array}$} & $\begin{array}{c}\text { \%age with total FDI } \\
\text { Inflows(+) }\end{array}$ \\
\cline { 3 - 4 } & & In Rs crore & In US \$ million & \\
\hline $\mathbf{1}$ & Mauritius & $286,876.42$ & $63,653.35$ & $\mathbf{3 9 . 2 5}$ \\
\hline $\mathbf{2}$ & Singapore & $76,646.31$ & $16,965.41$ & $\mathbf{1 0 . 4 6}$ \\
\hline $\mathbf{3}$ & Japan & $57,332.26$ & $12,209.99$ & $\mathbf{7 . 5 3}$ \\
\hline $\mathbf{4}$ & U.S.A & $47,189.84$ & $10,424.89$ & $\mathbf{6 . 4 3}$ \\
\hline $\mathbf{5}$ & United Kingdom & $41,957.55$ & $9,397.08$ & $\mathbf{5 . 7 9}$ \\
\hline $\mathbf{6}$ & Netherlands & $31,367.51$ & $6,919.11$ & $\mathbf{4 . 2 7}$ \\
\hline $\mathbf{7}$ & Cyprus & $28,872.79$ & $6,241.24$ & $\mathbf{3 . 8 5}$ \\
\hline $\mathbf{8}$ & Germany & $20,460.62$ & $4,547.70$ & $\mathbf{2 . 8}$ \\
\hline $\mathbf{9}$ & France & $13,138.98$ & $2,879.40$ & $\mathbf{1 . 7 8}$ \\
\hline $\mathbf{1 0}$ & Uae & $10,252.68$ & $2,229.16$ & $\mathbf{1 . 3 7}$ \\
\hline $\mathbf{1 1}$ & Switzerland & $9,410.31$ & $2,065.46$ & $\mathbf{1 . 2 7}$ \\
\hline $\mathbf{1 2}$ & Spain & $5,008.42$ & $1,103.36$ & $\mathbf{0 . 6 8}$ \\
\hline $\mathbf{1 3}$ & Italy & $4,808.97$ & $1,086.14$ & $\mathbf{0 . 6 7}$ \\
\hline $\mathbf{1 4}$ & South Korea & $4,494.11$ & 986.22 & $\mathbf{0 . 6 1}$ \\
\hline $\mathbf{1 5}$ & Hongkong & $3,983.84$ & 877.79 & $\mathbf{0 . 5 4}$ \\
\hline $\mathbf{1 6}$ & Caymen Islands & $3,646.30$ & 857.59 & $\mathbf{0 . 5 3}$ \\
\hline $\mathbf{1 7}$ & Sweden & $3,871.56$ & 849.69 & $\mathbf{0 . 5 2}$ \\
\hline $\mathbf{1 8}$ & British Virginia & $3,369.48$ & 752.60 & $\mathbf{0 . 4 6}$ \\
\hline & & & & \\
\hline
\end{tabular}

Table 3: Amount of foreign direct investment inflows country wise.

Singapore (9 per cent) during 2008 to August 2010 among top ten countries.

* It can also help to plug a country in the international trading system as well as promote a more competitive business environment [11].
* It is suggested that try to make decentralization of FDI projects in all over India. Do not grant them in only urban or facilitated region but must spread them in whole India.

\section{Conclusion}

India is attracting a low level of FDI largely due to poor business environment prevailing in the country. The investment climate in India has become much friendlier today than previous decades. Infrastructure is being developed and FDI policy is being liberalized to improve the situation. However, a lot is to be done if we want to emerge as one of the major export oriented manufacturing hub. Investors are showing their growing confidence in the immediate and medium term prospects of Indian Economy [12]. FDI off course might be one of the important sources of financing the economic development. However, one should not forget that FDI alone is not a solution for poverty eradication, unemployment and other economic ills. India needs a massive investment to achieve the goals of vision 20-20. Policy makers need to ensure transparency and consistency in policy making along with comprehensive long term development strategy.

\section{References}

1. http://www.dipp.nic.in/English/default.aspx

2. www.fdi.gov.in

3. www. Sebi.gov.in

4. http://www.rbi.org.in/home.aspx

5. Ministry of Commerce and Industry, Department of Industrial Policy and Promotion.

6. Macinko J, Starfield B, Shi L (2003) The Contribution of Primary Care Systems to Health Outcomes within Organization for Economic Cooperation and Development (OECD) Countries. OECD 38: 831-865.

7. Rajana RS, Rongalab S, Ghoshc R (2008) New Dimensions of Economic Globalization Surge of Outward FDI from Asia, World Scientific Press. Attracting Foreign Direct Investment FDI to India World Scientific Press.

8. Tseng W, Zebregs $\mathrm{H}$ (2002) Foreign Direct Investment in China: Some Lessons for Other Countries. International Monetary Fund 1-25.Tevelde DW (2001) Policies towards foreign direct Investment in developing countries, Emerging Issues and Outstanding Issues, London: Overseas Development Institute.

9. http://unctad.org/en/Pages/DIAE/FDI\%20Statistics/FDI-Statistics.aspx

10. Balasubramanyam VN, David S (2007) Does India need a lot more FDI 17: 1549-1555.

11. Economic Survey (2010) Ministry of Finance, Government of India, New Delhi.

12. Basu P, Nayak NC, Archana (2007) Foreign Direct Investment in India: Emerging Horizon. Indian Economic Review 42: 255-266. 